\title{
THE INFLUENCE OF ORGANIZATIONAL FACTORS ON RETURN-TO-WORK OUTCOMES
}

\author{
MICHELE CAVEEN \\ Health Systems Research and Consulting Unit, Centre for Addiction and \\ Mental Health, Toronto \\ CAROLYN S. DEWA and PAULA GOERING \\ Health Systems Research and Consulting Unit, Centre for Addiction and \\ Mental Health and Department of Psychiatry, University of Toronto
}

\begin{abstract}
This study explores the types of company policies and benefits that are associated with variations in return to work for workers with depression-related disability. Three financial institutions essentially following the same regulations and with a similar rate of depression-related short-term disability experienced some striking differences in their return-to-work outcomes. This mixed method study seeks to understand differences in the work environments and more specifically in disability management practices, and reflects on how these differences might have contributed to variations in return to work. Five themes emerged during the analysis of the qualitative data: (a) changing work environment, (b) leadership with respect to disability, (c) supportive managers, (d) accountability, and (e) cross-functional coordination. The similarities and differences among the three companies with respect to these themes help increase our understanding of the differences in the return-to-work outcomes.
\end{abstract}

The World Health Organization ranks depressive disorders as the leading cause of disability in high income countries such as Canada (WHO, 2001). Based on North American epidemiological surveys, 4 to $10 \%$ of working adults experience a major depressive episode in a given 12-month period (Kessler et al., 1994; Offord et al., 1996; Statistics Canada, 2003). Broadhead, Blazer, George, and Tse (1990) found that individuals with major depression had an almost five-fold greater risk of disability compared to those who were asymptomatic. The prevalence of depression and the increased likelihood of disability place a substantial economic burden on the workplace in terms of decreased productivity

We would like to thank the two anonymous reviewers for their helpful comments. We also would like to thank Dr. Jack Williams, who was the CEO of Toronto Rehab when he reviewed this article, and Dr. Sidney Kennedy of the University Health Network, Toronto, for their thoughtful suggestions, timely feedback, and ongoing support during the conduct of this study. Carolyn Dewa is grateful for the support provided by the Ontario Ministry of Health and Long-Term Care Career Scientist Awards. Quantitative data collection was supported by the Ontario Roundtable on Appropriate Prescribing. 
and work absences. Canadian work-related productivity losses due to depression were estimated to be $\$ 4.5$ billion in 1998 (Stephens \& Joubert, 2001). Although the effects of depressive disorders on the workplace are of rising concern, very little is known about how to effectively address this problem.

Using administrative data, previous work (Dewa, Goering, Lin, \& Paterson, 2002) examined the characteristics of workers who claimed depression-related disability benefits. The data were from three financial/insurance sector employers. Together, these companies had a national employee base of 60,000 workers. Although all three companies were from the same business sector, followed essentially the same regulations, and had a similar rate of depression-related short-term disability, there were some striking differences in the return-to-work outcomes.

This mixed method study provides an opportunity to explore questions raised by the quantitative data and to examine the perceptions and the voices of the people in the work environment who are responsible for managing the disability management and return-to-work process. In this paper, we seek to understand differences in the work environments and, more specifically, in disability management practices, and to reflect on how these differences might contribute to variations in return-to-work outcomes.

\section{BACKGROUND}

Research activity on workplace health as it relates to disability management, return to work, and treatment has primarily been targeted at physical health problems such as back injury, musculoskeletal problems, brain injury, cardiac illness, and chronic rheumatic diseases (Goldner et al., 2004). A number of studies suggest that certain work environment characteristics, including corporate culture and company policies/practices, are associated with lower rates of disability and may also play a role in disability outcomes (Habeck, Hunt, \& VanTol, 1998; Lewin \& Schecter, 1991; Shannon et al., 1996; Williams \& Westmorland, 2002).

Only a handful of studies have specifically examined the relationship between the work environment and mental illness-related disability outcome; even fewer studies have focused on workplace disability management approaches. Akabas and Gates (1997) used a qualitative approach to assess the relationship between workplace accommodation and successful employment of workers with mental illness. The study results showed that workplace responsiveness and accommodation differed between workers who were employed despite mental health problems and those who left work. The results also identified relationship accommodation (i.e., involving all relevant sources of social support in the return-to-work process) as an unmet need of this latter group.

Burton and Conti (1991) examined the impact of a program designed to monitor mental illnessrelated short-term disability by confirming diagnoses, reviewing treatment, facilitating access to appropriate care, and managing the employee's transition back into the workplace. The program was implemented in the First National Bank of Chicago. The trend toward increasing average days per short-term disability event was reversed with the implementation of this program. In a follow-up study, Conti and Burton (1994) reported that the average duration of psychiatric short-term disability decreased 
from 47.7 days prior to the program to an average of 32 days in the post-implementation period. McCulloch et al. (2001) demonstrated a positive impact on disability outcomes in a company that implemented a program in which the management of psychiatric short-term disability was coordinated by a behavioural health-care organization. As compared to nonparticipants, claimants managed under the new program experienced on average a 23\% (17.1 days) reduction in the duration of disability.

Evidence from the literature supports the hypothesis that the work environment, especially disability management practices, plays a role in disability outcomes. However, it is unclear how effective these practices may be for individuals with depression-related disability. Individuals who suffer from depression and other mental illnesses are likely to experience different problems (such as lack of concentration, maintaining stamina throughout the day, and managing time pressure and deadlines) than workers who have a physical disability (Mancuso, 1990). The study addresses the following question: What types of company policies, culture, and benefits are associated with variations in return to work for workers with depression-related disability?

\section{Conceptual Framework}

Workplace factors identified in the literature as important to the incidence and outcome of work disability were organized into a conceptual framework (Appendix 1). The conceptual framework was developed to help guide data collection and analysis. The framework focuses on disability management within the context of the work environment and as such does not include other factors, both external to the organization or internal to the individual, which may also play a role in the illness. The framework includes four components: (a) company environment (Habeck, Hunt, et al., 1998; Shannon et al., 1996; Williams \& Westmorland, 2002), consisting of organizational and business characteristics (such as size and organizational redesign initiatives), managerial style, and corporate culture characteristics (such as employee involvement and the leadership with respect to disability initiatives); (b) policies and procedures (Habeck, Hunt, et al., 1998; Habeck, Scully, VanTol, \& Hunt, 1998b; Lewin $\&$ Schecter, 1991) related to disability prevention and management initiatives (such as wellness programs, employee assistance programs, disability claims coordination, and modified or gradual work resumption); (c) short- and long-term disability benefit plans (Salkever, Goldman, Purushothama, \& Shinogle, 2000); and (d) outcomes as to the disability rate and return-to-work rate. The work environment and policies and procedures components of the conceptual framework were adapted from a framework developed by Habeck and Hunt et al. (1998).

\section{METHODS}

\section{Design/Data Sources}

This study uses a multiple-case study approach (Yin, 1994) consisting of a combination of quantitative and qualitative research methods. The study received approval from the University of Toronto Ethics Review Board. 
Quantitative data. This study included a secondary analysis of administrative data taken from three Canadian financial institutions-two banks and one insurance company-having a national base of 60,000 workers and representing $12 \%$ of their sector (Dewa et al., 2002). The primary sources of information for the study were each company's short-term disability claims, long-term disability claims, prescription drug claims, and occupational health department records (consisting of attending physician reports and occupational health progress notes). Because of its relatively smaller size, claims from one company were taken for short-term disability episodes beginning between January 1996 and December 1998. For the other two companies, data were abstracted for claims beginning in 1997 or 1998. The sample consisted of workers who were on short-term disability leave due to a depressive illness, and who were absent from work for at least 10 consecutive work days prior to their disability leave. For further description of the data source, see Dewa et al., 2002.

Qualitative data. Sources of organizational data for the qualitative portion of the study consisted of taped, semistructured interviews, documents, and written comments abstracted from occupational health records. An interview guide and focus group guide were developed to capture determinants of health in the workplace that were identified through the literature review and conceptual framework. (See Appendix 2 for type of information and sources.)

\section{Description of Cases}

In this multiple-case study, the unit of analysis or case is the organization. Data were collected and analyzed from all three financial institutions. To ensure the anonymity of participating institutions and, at the same time, help make the reader's journey through this paper smoother, the institutions were assigned pseudonyms. The paper refers to the two banks and the insurance company as Banks $\mathrm{R}$ Us, Master Bank, and Life Raft, respectively. A total of 1,520 workers on short-term disability leave with a diagnosis of depression were included in the sample. For employees with more than one depression-related short-term disability claim during the study period, data were obtained for the most recent episode. As a result, each employee was included in the dataset only once.

\section{Sampling}

Key informants were selected based on two criteria. First, they had to be directly involved with the disability management process during the time period covered by the study (1996-1998). Second, the informants had to have held one of the following positions during that period: occupational health nurse, disability case manager, medical director/advisor, or human resources staff member. Individuals were selected because their position in the company provided them with an in-depth knowledge of the work environment and the policies and practices governing disability management. The quantitative data abstractors were selected for a focus group interview because of their unique experience in reviewing and abstracting from the occupational health records of the three companies. Sampling was an iterative process, initially driven by the conceptual framework and then by data collection and analysis. A snowball sampling strategy was employed whereby new informants were identified by interviewees who felt that these individuals would be information rich. Additional people were interviewed until it 
became clear that no new information would be revealed. In 2001, a total of 11 one-on-one interviews were conducted, and four data abstractors participated in the focus group interview.

\section{Quantitative Analysis}

A comparative analysis of the companies was conducted to examine variations in their rates of depression-related disability, 12-month recurrence of disability due to mental illness, rates of return to work, rates of long-term disability, and rates of work termination after a short-term disability leave due to depression. In addition, the mean duration of a disability leave was calculated for each company. Chi-square was used to test for differences in these variables across sites.

\section{Qualitative Data Analysis}

Three analytic techniques — data reduction, data display, and conclusion drawing — as suggested by Miles and Huberman (1994), were employed. A within-case analysis was initially conducted to obtain coherent information on each case prior to doing a cross-case analysis. Analysis of each type of data (interviews, documents, and chart abstracts) occurred simultaneously. As part of data reduction, all text data were coded to generate categories and themes. Once categories were developed and coding was underway, the investigator searched for correspondence between the categories to identify patterns. As part of the within-case analysis, a description of each organization was written. To help summarize each case and to facilitate the process of comparing and contrasting between the three cases, a conceptually ordered display format (Miles \& Huberman, 1994) was employed. During the process of drawing conclusions, findings were corroborated by using triangulation of multiple data sources and methods.

\section{RESULTS}

Tables 1 and 2 describe each company's disabled population, and the work outcomes for depression-related short-term disability, respectively. The prevalence rates of depression-related short-term disability were comparable across the three firms. Differences were seen in the following outcomes: return to work, recurrence rates, termination of employment, transfer to long-term disability, duration of disability leave, and part-time accommodations. These differences will be described further in the discussion section.

\section{Disability Benefit Plans}

A summary of the disability benefit plans of each company is presented in Tables 3 and 4 . Banks R Us had a slightly more generous short-term disability plan with $100 \%$ short-term income protection coverage from the first day of employment. Of the three companies, Master Bank had the most generous long-term income protection plan (LTIP), providing a benefit equal to 70\% of the employee's salary. The cost of the LTIP benefit was also fully covered by the company. 


\section{Table 1}

\section{Description of Employees with Disabilities}

\begin{tabular}{|c|c|c|c|c|}
\hline Characteristics & $\begin{array}{l}\text { Life Raft }{ }^{1} \\
(n=124)\end{array}$ & $\begin{array}{c}\text { Banks R Us }{ }^{2} \\
\quad(n=467)\end{array}$ & $\begin{array}{l}\text { Master Bank }{ }^{3} \\
\quad(n=929)\end{array}$ & Statistics \\
\hline $\begin{array}{l}\text { Prevalence }^{\mathrm{a}} \\
\%(n)\end{array}$ & $2.2 \%(90)$ & $2.6 \%(467)$ & $2.5 \%(929)$ & \\
\hline $\begin{array}{l}\text { Previous SDIS episode } \\
\text { during prior 12-months } \\
\%(n)\end{array}$ & $15.3 \%(19)$ & $15.0 \%(70)$ & $10.6 \%(98)$ & $X^{2}=6.82, p=.0330$ \\
\hline $\begin{array}{l}\text { Male } \\
\%(n)\end{array}$ & $14.5 \%(18)$ & $12.8 \%(60)$ & $12.2 \%(113)$ & $\begin{array}{l}{ }^{1} X^{2}=23.56, p<.0001 \\
{ }^{2} X^{2}=60.26, p<.0001\end{array}$ \\
\hline $\begin{array}{l}\text { Female } \\
\%(n)\end{array}$ & $85.5 \%(106)$ & $87.2 \%(407)$ & $87.8 \%(816)$ & ${ }^{3} X^{2}=102.06, p<.0001$ \\
\hline $\begin{array}{l}\text { Mean age } \\
\text { (years) }\end{array}$ & $\begin{array}{c}38.7 \\
(20.9-61.3 \\
S D=8.967)\end{array}$ & $\begin{array}{c}41.1 \\
(20.0-61.6 \\
S D=8.794)\end{array}$ & $\begin{array}{c}39.9 \\
(20.2-64.6 \\
S D=8.861)\end{array}$ & $\begin{array}{l}F=4.93 \\
p=.0074\end{array}$ \\
\hline $\begin{array}{l}\text { Mean length of service } \\
\text { (years) }\end{array}$ & $\begin{array}{c}10.8 \\
(0.5-41.0 \\
S D=7.117)\end{array}$ & $\begin{array}{c}14.8 \\
(0.5-39.0 \\
S D=8.919)\end{array}$ & $\begin{array}{c}11.7 \\
(0.05-40.0 \\
S D=8.404)\end{array}$ & $\begin{array}{l}F=22.99 \\
p<.0001\end{array}$ \\
\hline $\begin{array}{l}\text { Management } \\
\%(n)\end{array}$ & $7.3 \%(11)$ & $11.3 \%(53)$ & $9.4 \%(87)$ & \\
\hline
\end{tabular}

Note. SDIS = short-term disability.

${ }^{\text {a}}$ For comparative purposes in calculating prevalence, only disability claims $(n=90)$ from 1997 and 1998 were included for Life Raft. ${ }^{b}$ Due to missing length of service values, there are 123 employees for Life Raft and 708 for Master Bank.

\section{Organizational Disability Management Themes}

Five themes emerged during the analysis of the qualitative data: (a) changing work environment, (b) leadership with respect to disability, (c) supportive managers, (d) accountability, and (e) crossfunctional coordination. There were similarities and differences in how the three companies and, more specifically, how their disability management practices demonstrated these five characteristics. Understanding these contexts can assist in interpreting the quantitative findings.

\section{Changing Work Environment}

All three companies were undergoing significant changes during the study time period. The forces and type of change facing the financial sector have been well described in a report by the Canadian Bankers Association (1997) to the federal government. 
Table 2

Work Outcome for Disabled Workers with Depression

\begin{tabular}{|c|c|c|c|c|}
\hline Work outcome & $\begin{array}{l}\text { Life Raft } \\
(n=124)\end{array}$ & $\begin{array}{l}\text { Banks R Us } \\
(n=467)\end{array}$ & $\begin{array}{c}\text { Master Bank } \\
\quad(n=929)\end{array}$ & Statistics \\
\hline $\begin{array}{l}\text { Return to work } \\
\%(n)\end{array}$ & $72.6 \%(90)$ & $72.4 \%(338)$ & $78.2 \%(727)$ & $\begin{array}{l}X^{2}=6.95 \\
p=.0310\end{array}$ \\
\hline $\begin{array}{l}\text { Terminated/retired } \\
\%(n)\end{array}$ & $13.7 \%(17)$ & $15.2 \%(71)$ & $3.8 \%(35)$ & $\begin{array}{c}X^{2}=61.90 \\
p<.0001\end{array}$ \\
\hline $\begin{array}{l}\text { Long-term disability } \\
\%(n)\end{array}$ & $13.7 \%(17)$ & $12.4 \%(58)$ & $18.0 \%(167)$ & $\begin{array}{l}\mathrm{X}^{2}=7.38 \\
p=.0249\end{array}$ \\
\hline $\begin{array}{l}\text { Duration of leave } \\
\text { (days) }\end{array}$ & $\begin{array}{c}106.4 \\
(15.0-269.0 \\
S D=63.406)\end{array}$ & $\begin{array}{c}90.3 \\
(11.0-556.0, \\
S D=64.497)\end{array}$ & $\begin{array}{c}100.3 \\
(11.0-512.0, \\
S D=66.994)\end{array}$ & $\begin{array}{l}F=4.70 \\
p=.0092\end{array}$ \\
\hline $\begin{array}{l}\text { Initial return to work } \\
\text { part-time } \\
\%(n)\end{array}$ & $64.4 \%(58)$ & $45.3 \%(153)$ & $4.3 \%(31)$ & $\begin{aligned} \mathrm{X}^{2} & =341.95 \\
p & <.0001\end{aligned}$ \\
\hline $\begin{array}{l}\text { Length of initial part-time } \\
\text { work }^{\mathrm{a}} \\
\text { (days) }\end{array}$ & $\begin{array}{c}48.8 \\
(5.0-217.0 \\
S D=42.034)\end{array}$ & $\begin{array}{c}30.4 \\
(0.0-386.8 \\
S D=34.195)\end{array}$ & $\begin{array}{c}21.4 \\
(7.0-49.0 \\
S D=8.712)\end{array}$ & $\begin{array}{l}F=8.36 \\
p=.0003\end{array}$ \\
\hline
\end{tabular}

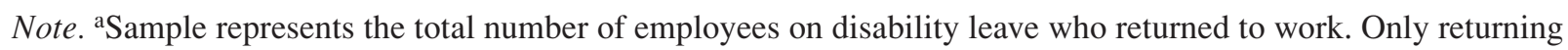
part-time employees who subsequently transferred to full-time employment were included in the numerator.

Life Raft, the insurance company, was just starting to undergo significant cultural and structural changes at the beginning of the study period. Culturally, the relationship between the company and its employees was transitioning from one where the company looked after the needs of its employees, a culture described as paternalistic by interviewees, to one where the employees had to take greater responsibility for themselves. For example, in the past employees had access to a fully subsidized dry cleaning service and cafeteria, and by the beginning of the study period both initiatives had been abandoned. In addition, the company introduced flexible benefits that provided employees with choices, rather than dictating coverage. Structurally, the company was amalgamating some of its branches (or agencies) and downsizing some of its divisions to close a financial gap that had been created by insurance price wars during the time leading up to the study period. The effects of the pending demutualization (shifting from a mutual company to a publicly traded company) were felt during the latter part of the study period when the company increased its emphasis on short-term financial gains.

Respondent \#1: There was some downsizing in some of the divisions depending on how they chose to close their gap. They were basically told that you got to recover this money. We had to get the money back so as of the day we go out as a stock company we are financially strong. And some of the things 
Table 3

Characteristics of Companies' Short-Term Disability Plans

\begin{tabular}{l|l|l|l}
\hline \multirow{2}{*}{ Characteristic } & \multicolumn{2}{|c}{ Company } \\
\cline { 2 - 4 } & Life Raft & Banks R Us & Master Bank \\
\hline Point of initiation & 10 consecutive days & 5 consecutive days & 5 consecutive days \\
\hline Salary coverage & $\begin{array}{l}\text { Minimum of 70\%, beyond } \\
\text { an accumulated max of 130 } \\
\text { days of salary continuance } \\
\text { (based on 1.25 days credit } \\
\text { per month of service) }\end{array}$ & $\begin{array}{l}100 \% \text { from 1 } \\
\text { service }\end{array}$ & $\begin{array}{l}70 \% \text { after 3 months continuous } \\
\text { service building to 100\% after } 6.5 \\
\text { years }\end{array}$ \\
\hline Duration & 26 weeks within a 12-month period & \\
\hline Administrator & Company's occupational health department & \\
\hline Payer & Company (self-insured) & \\
\hline
\end{tabular}

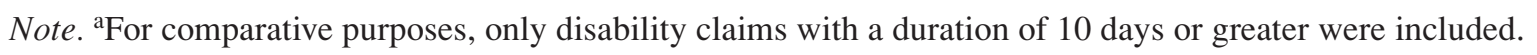

Table 4

Characteristics of Companies' Long-Term Disability Plans

\begin{tabular}{|c|c|c|c|}
\hline \multirow[t]{2}{*}{ Characteristic } & \multicolumn{3}{|c|}{ Company } \\
\hline & Life Raft & Banks R Us & Master Bank \\
\hline Point of initiation & \multicolumn{3}{|c|}{ After 26 weeks of short-term disability } \\
\hline Salary coverage & \multicolumn{2}{|c|}{$\begin{array}{l}\text { Mandatory 4-tiered flex benefits: } 50 \% \text { of } 1^{\text {st }} \$ 40 \mathrm{~K}+ \\
30 \% \text { balance to } 60 \% \text { of } 1^{\text {st }} \$ 40 \mathrm{~K}=40 \% \text { balance }+ \\
\text { annual cost of living adjustment }\end{array}$} & $\begin{array}{l}\text { Benefit is equal to } 70 \% \text { of salary } \\
\text { with optional 3-tiered flex benefits: } \\
70 \%+\text { cost of living adjustment or } \\
55 \% \text { with or without cost of living } \\
\text { adjustment }\end{array}$ \\
\hline $\begin{array}{l}\text { Conditions for } \\
\text { approval }\end{array}$ & \multicolumn{3}{|c|}{$\begin{array}{l}\text { Medically eligible, undergoing treatment, and willing to participate in return-to-work rehab } \\
\text { program. Eligibility ends when employee terminates employment or reaches age } 65\end{array}$} \\
\hline Administrator & \multicolumn{3}{|l|}{ Third party insurer } \\
\hline Payer & \multicolumn{2}{|l|}{ Fully paid by employees } & $\begin{array}{l}70 \% \text { of salary benefit is fully paid by } \\
\text { company. Indexing feature for } 70 \% \\
\text { coverage is paid by employee. For } \\
55 \% \text { salary coverage, the company } \\
\text { reimburses worker with extra flex } \\
\text { credits to be used on other benefits }\end{array}$ \\
\hline
\end{tabular}


they were looking at were making divisions leaner, having less people to do the same work. And so it was a lot more stressful for employees.

Unlike Life Raft, Banks R Us had experienced its cultural shift in the years immediately preceding the study. In 1997, the corporate culture was fairly positive with open communication, flexible benefits and work options, and involvement of all employees in the bonus and share option programs. The strategic plan was widely communicated to staff to ensure alignment of personal business objectives with the overall plan. On the downside, the interviewees indicated the company placed a far greater emphasis on managers delivering financial results than focusing on people.

Respondent \#4: It was primarily result driven, so bottom-line results. I can remember it was always you don't get paid for managing people. You get paid for what you know and how well the results are. So there wasn't a great deal of emphasis put on the soft skills of people managers. It was more crack the whip and get the work done.

Also during the study period, the bank was undergoing a tremendous amount of change due to computerization of processes, closure of branches, a merger, and implementation of a number of special projects geared toward increasing operational efficiencies.

In the years leading up to the study period, Master Bank had been very progressive in ensuring managers were supportive of their staff. Managers were required to participate in training programs to develop their people management skills; they received feedback on how well they were doing via a 360-degree evaluation process. During the study time period, the company gradually shifted away from valuing people-oriented managers to valuing results-oriented managers. The appointment of a new chairman led to a drastic change in philosophy and an even greater focus on the bottom line. Master Bank was undergoing similar changes to Banks R Us, including a merger, increase in e-business versus retail sales branches, branch closure, and a shift from a service-oriented company to salesoriented company. The effects of these changes were felt throughout the company and led to employees feeling decreased autonomy over their workload and increased job insecurity.

Respondent \#9: Prior to 1997 I would have talked to you very happily about supportive managers and things like that. The e-commerce bank and the call centres have been experiencing a $70 \%$ turnover rate in managers. And so I will just be blunt with you and say that the standard of management or supervisors in call centres is very sad and we see that reflected here. In '97-'98 that was the transition. It used to be what have you done for us in the last 10 years, and now it is what have you done for us last week and what are you doing for us next week. You might think I am joking but that is how short the targets are set.

Interviewees from all three companies felt that the stress on employees brought on by these changes translated into increased disability claims due to mental or nervous disorders during the study time period. Although all three companies offered health promotion programs to help employees deal with stress in the workplace, none of these programs were specifically targeted at preventing depression-related disability. The programs consisted primarily of health education sessions offered either by the Employee Assistance Program (EAP) or occupational health department. Participation in these programs was purely voluntary. Targeted programs were usually developed and offered only at the request of individual departments.

Of the three companies, it would appear that only Banks R Us put in place a change management program to help employees develop coping mechanisms to deal with constant change in the workplace. 
However, the change management program was delivered only at the request of departments and it did not appear to have been broadly disseminated within the company. Individuals who took the program also doubted its effectiveness in alleviating their stress level and in providing them with the necessary tools to cope with constant change.

Furthermore, a number of statements made during the interviews at Banks $\mathrm{R}$ Us indicated that older employees experienced a greater level of stress. According to interviewees, the changes taking place at Banks R Us were more likely to affect seasoned employees than junior employees. The reasons cited were that the more senior employees were assigned to work on confidential projects and/or on merger-related work while maintaining their regular workload.

Respondent \#4: We were starting to see a more senior, longer term employee, more senior in the bank with no previous record of disability leave at all, no sickness, no casual absence record, your strong performers, consistent strong performers starting to go down. They were going down on us. And as they went down — and I mean sick with mental depression—as they went down they went down harder and longer than we had had experience with. We put that down to thinking that it was all the special projects, all the uncertainty, the change, along with where the bank was going through that period of time and constant downsizing and trimming and making do with fewer, people leaving and not being replaced.

\section{Leadership with Respect to Disability}

Leadership with respect to preventing and managing disabilities varied across the three companies. Leadership appeared to be most evident at Banks R Us. First, the senior executive team had developed a very good relationship with the two medical advisors, and the team was very receptive to suggestions on how best to manage disability. This gave the occupational health department the opportunity to gain approval for new prevention and disability programs without having to go through several layers of management.

Respondent \#6: In that if there are issues that I am concerned about I can go right to the top of the house. So that has been very helpful. Very helpful in terms of promoting an agenda such as you need to do something on the disability side of things. You don't have to go through too many layers.

Second, the chief executive officer (CEO) at the time sent a circular to all employees confirming the company's commitment to reintegrating and accommodating employees on disability leave back into the workforce. Occupational health staff used the circular as leverage in their negotiations with employees or managers who were resistant to the return-to-work and accommodation process. Third, a return-to-work case manager position was created and funds were designated to help pay for some accommodations, albeit primarily targeted at physical disabilities.

At Life Raft, the senior management was primarily focused on accommodating employees with disabilities. This commitment was communicated to staff through the written disability policies and was further confirmed by the interviews. Managers essentially were required to support returning employees with the necessary level of accommodation, such as temporary part-time hours. The company also sponsored a number of senior management seminars on the employment of workers with disabilities. 
Respondent \#3: I know I have been involved in some conferences and senior management has participated in those conferences talking about disabled people, hiring them and retaining them in the workplace.

Leadership at Master Bank played a role in the development of a health and well-being strategy to help guide the health promotion and prevention initiatives. They also supported the inclusion of a training module on depression in the workplace in the leadership development program. The company was very progressive in adopting a new disability management program in the latter part of the study period.

\title{
Supportive Managers
}

Despite variations in management styles across the companies, all interviewees highlighted the importance of managers in the disability management process. It was their experience that managers who were supportive-described as fostering open communication, setting clear objectives, and providing recognition and career development opportunities—-helped promote a healthier work environment for their staff. As previously mentioned, in the years leading up to the study period, Master Bank put a lot of emphasis on hiring and developing supportive managers. The emphasis started shifting toward more results-oriented managers in 1997. During the same time period, Banks R Us, having realized the importance of supportive managers, was just starting to put in place practices to foster the hiring and development of supportive managers. Subsequent to the study period, Life Raft also put in place training programs to develop this attribute in their managers.

However, supportive management was not always put into practice. Interviewees in all three companies believed several of their employees took depression-related short-term disability leaves instead of dealing with workplace issues. In essence, they felt that often the disability was not medically warranted, but rather a tactic used by employees to avoid dealing with workplace problems or conflicts with managers. Indeed, that mental illness is often discounted as a true illness may lie at the core of this interpretation.

\begin{abstract}
Respondent \#1: A lot of times like [sic] we had an increase in mental and nervous claims and a lot of that is people just don't get along with their manager, and instead of thinking I'm going to quit my job here and get something somewhere else, they go on disability. There is a different mentality in terms of benefits that people have. A lot of people have this attitude that I paid for this benefit, and do it. This company owes me this. I am going off on claim. This manager is screaming. So I am not going to deal with it.
\end{abstract}

\section{Accountability}

The issue of accountability came up repeatedly during the interviews. There were at least three steps in the disability management process where accountability was either unclear or was felt to be inappropriately assigned. These steps included identifying workers with disabilities, adjudicating shortterm claims, and deciding on return-to-work dates.

In all three companies, there was a lack of accountability in informing the occupational health departments of absences. According to corporate policies, managers were responsible for informing the occupational health department of an employee's absence from work due to illness, and his or her 
eligibility for short-term income replacement. This notification should have taken place as soon as the employee had been off work for the designated period of time. In reality, occupational health would often hear of an absence weeks after the worker had stopped working. This lapse severely affected the opportunity for early identification and intervention, and was cited by all interviewees as the most common deviation from the policies and procedures. Most of the interviewees felt the reasons for this deviation were that the managers were unaware of their responsibilities or failed to see the overall benefits of informing occupational health of absences as early as possible in the process.

Respondent \# 2: The policy was incidental because really it was quite vague and in its implementation too. Sometimes it was 3 or 4 months before we knew the person was off, for example. And by that time the motivation for an employee to get back to work after sitting at home for 3 months, perhaps not getting good medical care or feeling alienated because no one has called them, isn't very efficient.

At the two banks, the occupational health nurses were responsible for adjudicating short-term disability claims and had the authority to decline claims based on lack of medical evidence. At Life Raft, the human resources group had the role of claim adjudicator, while the occupational health department was responsible for overseeing the medical evidence supporting the claim. Because of the dual level of responsibilities with respect to adjudication at Life Raft, it often took a long time for decisions to be made. The human resources group felt that the nurses were too lenient, while the occupational health group felt that human resources did not act on their recommendations and were uncomfortable with rejecting claims.

Respondent \#3: I would phone some of the doctors because the information was too sparse and really try to find out what is going on, whether treatment was optimal. We did all that quite conscientiously but the problem that we had was that the ones that would fall into the group that this is not supported, either because of duration or because it just didn't add up—we had no teeth here [sic]. It was just sort of frustrating to us because you could see these people using the system, but there was no way of stopping them. HR had the total say, we had no control over that whatsoever. We would give them the information but unfortunately they just didn't, eh [sic], they were very reluctant to, you know, dig in their heels on these.

Accountability for deciding when an employee could come back to work was placed on the shoulders of the employee's personal physician at Life Raft and Master Bank, and to a lesser extent at Banks R Us. Banks R Us was just starting to educate workers with disabilities and managers on the differences between the responsibilities of the attending physician and those of occupational health. The physician was responsible for the diagnosis and prognosis, and the occupational health department was responsible for managing the company's paid disability leave and orchestrating the return-to-work process. The case managers were starting to be much more proactive in developing return-to-work plans for workers with disabilities, instead of waiting for the green light from the attending physician.

Respondent \#4: We have got managers realizing that they need to participate, we have got employees realizing that you can be classed sick and be off work but you can come back early and start a graduated return to work. That was a huge shift to get managers to accept that employees could come back to part-time. It was kind of an all-or-nothing approach that we were trying to shift through '96-'97'98. We were heavily into it during that period of time. '96 we started shifting and '97-'98 we were really following it, and it was well entrenched, I think. We were still trying to get managers and employees to buy into it and understand it, but we weren't taking no for an answer. It was a tough time. 
At the other end of the spectrum, Life Raft and Master Bank relied more heavily on the recommendations of the attending physician for return-to-work dates and requirements for accommodations.

\section{Cross-Functional Coordination}

The level of communication and collaboration between the different players in the disability management process, especially with respect to return to work, varied across the three companies. The lack of cross-functional coordination was most evident at Life Raft and Master Bank. At Life Raft, the occupational health nurses tended to have a good rapport with employees with disabilities, and through frequent contacts with them were able to identify personal and work-related issues. A wealth of information on work-related issues was found in the disability claim records during data abstraction; however, based on the interviews there appeared to have been very little action taken to help resolve these issues. The players in the process-manager, human resources, employee, and occupational healthoften did not work together as a cohesive team to develop and implement a return-to-work plan. For example, the occupational health nurse would inform human resources of workplace issues and it would then be the responsibility of the human resources group to contact the manager, not necessarily involving the nurse in further discussions.

At Master Bank, there was also a lack of teamwork when it came to returning an employee with disabilities to work. The doctor would dictate the employee's return date and the level of accommodation required, and the manager would decide if, from a business perspective, the bank was able to provide the accommodation.

Respondent \#10: Again back in the old process there wasn't a whole lot of modified return to work and there wasn't a lot of communication between occupational health and the business. If I would say to the manager, this person can come back 4 hours a day, the manager would call back and say I can't accommodate this and they shouldn't come back until they are ready to hit the ground running at full capacity.

Cross-functional coordination with respect to the return-to-work process was much more evident at Banks R Us. The occupational health staff played more of a mediator role in trying to get employees back to work. They worked with the manager and the employee to develop a formal return-to-work plan. Occupational health staff also had senior management support in ensuring all members of the team were involved in the process.

There appeared to be very good coordination at Life Raft and Banks R Us with respect to managing long-term disability claims. In both companies, the occupational health staff ensured a smooth transition between short- and long-term disability claims by following cases until they had been adjudicated by the third party insurer. At Life Raft, the occupational health staff also continued to follow workers who were scheduled to return to work shortly after switching to long-term disability. At Banks R Us, a team was put in place to coordinate the activities with the third party insurer. In contrast, at Master Bank there was a tendency for the nurses to discontinue managing a claim as soon as the disabled worker applied for longterm disability. The full responsibility for managing the claim would then fall to the third party insurer.

Respondent \#8: Employees felt disconnected. We had more people going on LTD because nobody was there to provide an alternative process or any kind of support for them to figure out or to constructively accommodate them back to work. 


\section{Summary of Qualitative Results}

A summary of the qualitative results is included in Table 5. The table highlights some of the similarities and differences between the three work sites with respect to the five themes. All three companies were similar in the extent to which they were undergoing organizational change. The companies were also similar in their lack of accountability in identifying workers with disabilities, and they acknowledged that this lapse may have resulted in loss of opportunities for early intervention. Banks R Us differentiated itself from the other two companies in the area of leadership, cross-functional coordination, and clear accountability for return-to-work decisions, while Master Bank was stronger than the other two companies in valuing supportive management practices.

Table 5

Summary of Qualitative Results

\begin{tabular}{|c|c|c|}
\hline \multirow[t]{2}{*}{ Themes } & \multicolumn{2}{|c|}{ Evidence } \\
\hline & Lower & Higher \\
\hline Changing work environment & & $\begin{array}{l}\text { Life Raft } \\
\text { Banks R Us } \\
\text { Master Bank }\end{array}$ \\
\hline Leadership & $\begin{array}{l}\text { Life Raft } \\
\text { Master Bank }\end{array}$ & Banks R Us \\
\hline Supportive managers & $\begin{array}{l}\text { Life Raft } \\
\text { Banks R Us }\end{array}$ & Master Bank \\
\hline \multirow[t]{3}{*}{ Accountability } & $\begin{array}{l}\text { Adjudication: } \\
\text { Life Raft }\end{array}$ & $\begin{array}{l}\text { Adjudication: } \\
\text { Banks R Us } \\
\text { Master Bank }\end{array}$ \\
\hline & $\begin{array}{l}\text { Return to work: } \\
\text { Life Raft } \\
\text { Master Bank }\end{array}$ & $\begin{array}{l}\text { Return to work: } \\
\text { Banks R Us }\end{array}$ \\
\hline & $\begin{array}{l}\text { Identifying workers with disabilities: } \\
\text { Life Raft } \\
\text { Banks R Us } \\
\text { Master Bank }\end{array}$ & \\
\hline \multirow[t]{2}{*}{ Cross-functional coordination } & $\begin{array}{l}\text { Return to work: } \\
\text { Life Raft } \\
\text { Master Bank }\end{array}$ & $\begin{array}{l}\text { Return to work: } \\
\text { Banks R Us }\end{array}$ \\
\hline & $\begin{array}{l}\text { Long-term disability: } \\
\text { Master Bank }\end{array}$ & $\begin{array}{l}\text { Long-term disability: } \\
\text { Life Raft } \\
\text { Banks R Us }\end{array}$ \\
\hline
\end{tabular}




\section{DISCUSSION}

The rate of depression-related disability was not significantly different among the three work sites. Primary differences were associated with the average duration of short-term disability, and the performance of the sites on the three categories of disability outcomes: (a) return to work, (b) quit/ retired/terminated, and (c) transfer to long-term disability. The qualitative data analysis revealed some similarities, especially with respect to organizational change and stability. It also identified a number of differences in management styles and in disability management practices among the three work sites, which may help explain the quantitative findings.

\section{Work Environment and Disability}

Disability rate. The rate of depression-related disability during the 2-year period (1997 and 1998) ranged from 2.2\% for Life Raft to approximately 2.5\% for Banks R Us and Master Bank. The company descriptions and the theme of changing work environment provide some insight as to why there were essentially no differences in the rates of disability due to depression among the three work sites. It is well documented in the literature that psychosocial work factors, such as lack of control, high workload, and job insecurity are associated with mental illnesses, including depression (Ferrie, Shipley, Marmot, Stansfeld, \& Smith, 1995; Karasek 1979; Niedhammer, Goldberg, Leclerc, Bugel, \& David, 1998; Stansfeld, Fuhrer, Shipley, \& Marmot, 1999). During 1997 and 1998, all three companies were experiencing tremendous changes that resulted in employees feeling they had little control over their work and careers. The impact of these changes on employee health coupled with the lack of targeted disability prevention programs in all three companies could partially explain the similarities found in prevalence rates of depression-related disability.

Disability and employee status. Although all employees were affected to some degree by organizational and/or cultural changes, interviewees at Banks R Us indicated that older, more seasoned employees felt the brunt of these changes. Interestingly, this is the only company that had a greater proportion of employees with depression between the ages of 36 and 55 than would have been expected based on the characteristics of the total employee base. The quantitative data therefore appear to corroborate the perception of the interviewees that the job stressors in Banks R Us might have been greater for older employees.

Recurrence rate. Master Bank experienced a lower recurrence rate of depression-related disability as compared to the other two companies. This lower recurrence rate occurred despite the fact that changes experienced by Master Bank paralleled those at Banks R Us and preceded the onset of changes at Life Raft. With more supportive managers, Master Bank was perhaps in a better position than the other two companies to alleviate manager-employee conflicts and to address other types of workplace issues, thus reducing the number of disability leaves due to depression. A number of other studies support the finding that a high level of social support from supervisors is predictive of better mental health of employees (Kawakami, Haratani, \& Araki, 1992; LaRocco, House, \& French, 1980; Parkes, Mendham, \& Von Rabenau, 1994; Neidhammer et al., 1998; Stansfeld et al., 1999). 


\section{Disability Outcomes}

In all three companies the preferred disability outcome was early return to work, followed by long-term disability and then termination of employment.

Return to work. Employees on disability leave from Master Bank were more likely to return to work than those from Banks R Us and Life Raft. It is difficult to understand from the qualitative data why this outcome was different at Master Bank. Apart from the theme of supportive managers, Master Bank did not appear to perform as well in the other areas. In addition, during the study time period Master Bank was drastically shifting away from valuing people-oriented managers. Despite this shift, there may have been some residual effects of having valued supportive management practices in the past. Also, the managers were sensitized through the leadership program to the needs of employees with depression, thus ensuring that they were better equipped at supporting their employees through the disability management process. This result highlights the importance of the manager's role in the return-to-work process.

Length of disability. Although Master Bank had the highest return-to-work rate, Banks R Us had a shorter duration of disability leave. The themes of leadership, accountability, and cross-functional coordination provide insight as to the shorter length of disability experienced at Banks R Us as compared to the other two companies. Senior management provided the occupational health staff with a clear mandate to return employees with disabilities to work as early as possible. They strengthened their commitment by creating a position whose main accountability was to work with managers and employees to develop and coordinate a return-to-work plan. Occupational health staff were also empowered to try different initiatives in order to support employees with their return-to-work plans. Habeck, Scully, et al. (1998) observed that companies successful in limiting their disability incidence and duration had a systematic approach to return-to-work accommodation. The Canadian Centre on Disability Studies (Bilsker, Gilbert, Myette, \& Stewart-Patterson, 2002) identified "early return to work with innovative accommodation techniques" (p. 43) as a best practice in disability management. On the other hand, both Master Bank and Life Raft were more passive, usually waiting for the attending physician's recommendations with respect to return-to-work date and accommodation level.

Of the three companies, occupational health nurses at Life Raft most frequently contacted workers during their disability leaves. This was clearly evident from the volume and quality of information in the disability claim records. Not only did the nurses collect medical information such as symptoms and prognosis, but they also collected information on personal and workplace issues contributing to the disability. However, the frequent contacts and the wealth of information on each claim did not translate into increased or early return to work. On the contrary, workers were more likely to be on disability leave for a longer period of time from Life Raft than the other two companies. The lack of cross-functional coordination between all the players involved in the process at Life Raft, and the lack of accountability in adjudicating claims, may have contributed to the information not being effectively used by all parties to help employees get back to work.

Part-time accommodation. Interviewees from all three companies indicated that a modified work schedule was the most common form of accommodation for workers with depression. At both Life 
Raft and Banks R Us, employees were more likely to return to work initially on a part-time basis than at Master Bank. The theme of leadership supports this finding in that both Life Raft's and Banks R Us' senior management strongly encouraged gradual rehabilitation of employees with disabilities, while at Master Bank accommodation appeared to have been left up to the individual manager's discretion. What is surprising is that the higher proportion of part-time accommodation did not translate into early return to work at Life Raft, as it did at Banks R Us. This finding is even more puzzling given the possible financial incentive for Life Raft's employees to return to work. Life Raft employees who returned from disability leave received $100 \%$ of their salary for the hours worked and their short-term disability benefit percentage ( $70 \%$ to $100 \%$ depending on the number of remaining absence credits) for the balance of the hours, while at Banks R Us employees with disabilities received $100 \%$ of their salary whether they worked or not. Differences in duration of leave between the two companies may be related to another aspect of their disability practices. At Banks R Us, case managers were accountable for returning employees back to work early and used part-time hours as a means to do so, while at Life Raft the accountability was primarily left to the employee's medical doctor.

Long-term disability. Employees at Master Bank were more likely to go on long-term disability than employees at the other two companies. The relatively generous long-term disability plan, the low frequency of contacts between employees on disability leave and occupational health, and the lack of cross-functional coordination between occupational health and the long-term disability providers could all have played a role in this outcome. Salkever et al. (2000) found that the generosity of the long-term benefit plan was negatively related to return to work and positively related to length of disability. In addition, both Life Raft and Banks R Us were very proactive at managing the transition between shortand long-term disability. For example, Banks R Us rarely sent long-term disability packages to employees during the fourth month of short-term disability, even though this practice was contrary to their formal policies. Instead, case managers tended to send the information packages out at the very end of the 26-week period with the intention of communicating to the employee that long-term disability was not a right.

\section{Limitations}

The following limitations should be kept in mind when interpreting the study results. The diagnosis of depression was taken directly from the claim forms as provided by the attending physician. There were no clinical assessments performed to confirm a diagnosis of depression. Findings from previous work (Dewa, Hoch, Goering, Lin, \& Paterson, 2003) increase our confidence that a certain proportion of the workers with depression-related short-term disability likely had depression. In previous findings, the majority of disabled workers received antidepressants and used them, for the most part, according to aggressive treatment guidelines.

To protect the confidentiality of workers, employees were not interviewed. In addition, the dataset was anonymized so it was not possible to identify specific workers. Consequently, the researcher obtained only the perspective of the occupational health and human resources employees. Ideally, the

researcher would have had the opportunity to spend time working in the companies alongside of the employees to obtain an in-depth understanding of the corporate culture. 


\section{Implications for Disability Management Practices}

Based on these findings, three areas could be targeted for interventions: (a) leadership in disability initiatives, (b) early intervention, and (c) supportive managers. First, organizational leaders should make their commitment to disability management highly visible to all employees by endorsing policies and practices that clearly lay out accountabilities, and by fostering collaboration among all parties involved in the disability management process. This communication could be done by sending out, on a yearly basis, communiqués to the employees informing them of the company's legal obligations, the policies that are in place to support the legislation, the role that employees play in the process, and the company's performance with respect to disability management. Banks R Us is a good example of how a circular from the chairman on the company's commitment to reintegrating all workers with disabilities was used as leverage by occupational health staff in their return-to-work discussions with employees and managers. Going a step further and regularly informing employees of disability management initiatives would likely lead to a greater awareness of accommodation roles and resources.

Second, early intervention initiatives should be incorporated into the disability management process. In the previous study (Dewa et al., 2003), episodes of short-term depression-related disability were 12 to 34 days shorter for workers who received an antidepressant within 30 days of initiating their short-term disability. All three companies had significant delays in the identification of workers with disabilities. It was not unusual for occupational health staff to be advised of a worker's disability weeks and sometimes even months after the individual had been off work. There is an opportunity in all three companies to potentially shorten the average length of depression-related disability leaves by clearly laying out accountabilities and timelines in the disability policies and by educating all relevant parties on the overall benefits of early intervention through a mandatory training program. A computer-based absence reporting system and/or financial incentives for managers to report short-term disability absences to occupational health could also be explored.

Lastly, supportive behaviours should be developed and encouraged in managers. These managers would then be better prepared to work through issues with their staff in the hope of circumventing some disability leaves or in helping their employees to return to work. As Bilsker et al. (2002) eloquently point out: "Managers are the key to operationalizing corporate strategy. By adopting a participative and quality management approach, they can empower and engage workers in the identification and remediation of unhealthy work conditions" (p. 50).

\section{Conclusion}

Disability management and depression are complex issues that reflect the interplay of many psychosocial and medical factors. Given this high level of complexity, it is difficult to identify all the factors that may have influenced the depression-related short-term disability rates and return-to-work rates across the three work sites. The qualitative results shed light on some of the workplace factors, and provide a rich description not only of the depression-disability management context in each company, but also of the work environment in general. Future studies are needed to better understand the relationship between all of the variables, psychosocial and clinical, which may influence depressionrelated disability, and to document workers' points of view. 


\section{RÉSUMÉ}

Cette étude explore le lien entre des données sur le retour au travail d'employés souffrant de dépression, et les types d'avantages sociaux et de politiques qui s'appliquent en cette matière dans les milieux de travail. Nous avons observé des variations frappantes entre 3 entreprises qui appliquent essentiellement les mêmes règlements et ont des taux similaires d'invalidité à court terme due à la dépression. Nous avons utilisé une approche à la fois quantitative et qualitative pour comprendre comment des différences dans l'environnement de travail (et plus particulièrement dans la gestion de l'invalidité au travail) pouvaient avoir un effet sur ces variations. L'analyse des données qualitatives a fait ressortir 5 thèmes: (a) les changements dans l'environnement de travail; (b) la conscience des problèmes au niveau de la direction; (c) le soutien des gestionnaires; (d) les diverses responsabilités; (e) la coordination interfonctionnelle. Les ressemblances et les différences que nous avons notées, pour chacun des thèmes, entre les 3 entreprises nous ont ainsi permis de mieux comprendre les variations que nous avions observées.

\section{REFERENCES}

Akabas, S.H., \& Gates, L.B. (1997). Mental health disorders with workplace consequences: Accommodation through a disability management model. New York: Center for Social Policy and Practice in the Workplace, Columbia University School of Social Work.

Bilsker, D., Gilbert, M., Myette, T.L., \& Stewart-Patterson, C. (2002). Depression and work function: Bridging the gap between mental health care and the workplace. Vancouver: Mental Health Evaluation and Community Consultation Unit, University of British Columbia.

Broadhead, W.E., Blazer, D.G., George, L.K., \& Tse, C.K. (1990). Depression, disability days, and days lost from work in a prospective epidemiological survey. Journal of the American Medical Association, 264(19), 2524-2528.

Burton, W.N., \& Conti, D.J. (1991). Value-managed mental health benefits. Journal of Occupational Medicine, 33(3), 311-313.

Canadian Bankers Association. (1997). Our vision of the future of the Canadian financial sector. Submission to the Federal Taskforce. Retrieved January 7, 2003, from http://www.cba.ca

Conti, D.J., \& Burton, W.N. (1994). The economic impact of depression in a workplace. Journal of Occupational Medicine, 36, 983-988.

Dewa, C., Goering, P., Lin, E., \& Paterson, M. (2002). Depression-related short-term disability in an employed population. Journal of Occupational and Environmental Medicine, 44(7), 628-633.

Dewa, C., Hoch, J.S., Goering, P., Lin, E., \& Paterson, M. (2003). Use of antidepressants among Canadian workers receiving depression-related short-term disability benefits. Psychiatric Services, 54(5), 724-729.

Ferrie, J.E., Shipley, M.J., Marmot, M.G., Stansfeld, S., \& Smith, G.D. (1995). Health effects of anticipation of job change and non-employment: Longitudinal data from the Whitehall II study. British Medical Journal, $311,1264-1269$.

Goldner E., Bilsker, D., Gilbert, M., Myette, L., Corbiere, M., \& Dewa, C. (2004). Disability management, return to work and treatment. HealthcarePapers, 5(2), 76-90.

Habeck, R.V., Hunt, H.A., \& VanTol, B. (1998). Workplace factors associated with preventing and managing work disability. Rehabilitation Counseling Bulletin, 42(2), 98-143.

Habeck, R.V., Scully, S.M., VanTol, B., \& Hunt, H.A. (1998). Successful employer strategies for preventing and managing disability. Rehabilitation Counseling Bulletin, 42(2), 144-161.

Karasek, R.A. (1979). Job demand, job decision latitude, and mental strain: Implications for job redesign. Administrative Science Quarterly, 24, 285-308.

Kawakami, N., Haratani, T., \& Araki, S. (1992). Effects of perceived job stress on depressive symptoms in bluecollar workers of an electrical factory in Japan. Scandinavian Journal of Work Environment and Health, 18, 195-200. 
Kessler, R.C., McGonagle, K.A., Zhao, S., Nelson, C.B., Hughes, M., Eshleman, S., et al. (1994). Lifetime and 12-month prevalence of DSM-111-R psychiatric disorders in the United States: Results from the national comorbidity study. Archives of General Psychiatry, 51(8), 8-19.

LaRocco, J.M., House, J.S., \& French, J.R.P. (1980). Social support, occupational stress, and health. Journal of Health and Social Behavior, 21, 202-218.

Lewin, D., \& Schecter, S.M. (1991). Four factors lower disabilities rates. Personnel Journal, 70(5), 99-103.

Mancuso, L.L. (1990). Reasonable accommodation for workers with psychiatric disabilities. Psychosocial Rehabilitation Journal, 12(2), 3-19.

McCulloch, J.M., Ozminkowski, R.J., Cuffel, B., Dunn, R.L., Goldman, W., Kelleher, D., \& Comporato, A. (2001). Analysis of managed psychiatric disability program. Journal of Occupational and Environmental Medicine, 43(2), 101-109.

Miles, M.B., \& Huberman, A.M. (1994). An expanded source book: Qualitative data analysis (2nd ed.). Thousand Oaks, California: SAGE Publications.

Neidhammer, I., Goldberg, M., Leclerc, A., Bugel, I., \& David, S. (1998). Psychological factors at work and subsequent depressive symptoms in the GAZEL cohort. Scandinavian Journal of Work Environment and Health, 24, 91-113.

Offord, D.R., Boyle, M.H., Campbell, D., Goering, P., Lin, E., Wong, M., \& Racine, Y.A. (1996). One-Year prevalence of psychiatric disorder in Ontarians 15 to 64 years of age. The Canadian Journal of Psychiatry, 41(9), 559-563.

Parkes, K.R., Mendham, C.A., \& Von Rabenau, C. (1994). Social support and the demand-discretion model of job stress: Tests of additive and interactive effects in two samples. Journal of Vocational Behavior, 44, 91-113.

Salkever, D.S., Goldman, J., Purushothama, M., \& Shinogle, J. (2000). Disability management, employee health and fringe benefits and long-term disability claim for mental disorders: An empirical exploration. Milbank Quarterly, 78, 79-113.

Shannon, H.S., Walters, V., Lewchuk, W., Richardson, J., Moran, L.A., Haines, T., \& Verma, D. (1996). Workplace organizational correlates of lost-time accident rates in manufacturing. American Journal of Industrial Medicine, 29, 258-268.

Stansfeld, S.A., Fuhrer, R., Shipley, M.J., \& Marmot, M.G. (1999). Work characteristics predict psychiatric disorder: Prospective results from the Whitehall II study. Occupational and Environmental Medicine, 56, 302-307.

Statistics Canada. (2003). Canadian community health survey: Mental health and wellbeing. Retrieved November 9, 2005, from http://www.statcan.ca/Daily/English/030903/d030903a.htm

Stephens, T., \& Joubert, N. (2001). The economic burden of mental health problems in Canada. Chronic Diseases in Canada, 22(1), 18-23.

Williams, R.M., \& Westmorland, M. (2002). Perspectives on workplace disability management: A review of the literature. Work, 19(1), 87-93.

World Health Organization (WHO). (2001). The world health report 2001. Mental health: New understanding, new hope. Geneva, Switzerland: Author.

Yin, R.K. (1994). Case study research: Design and methods (2nd ed.). Applied Social Research Methods Series, Vol. 5. Thousand Oaks, California: SAGE Publications. 
APPENDIX 1

\section{Conceptual Framework}

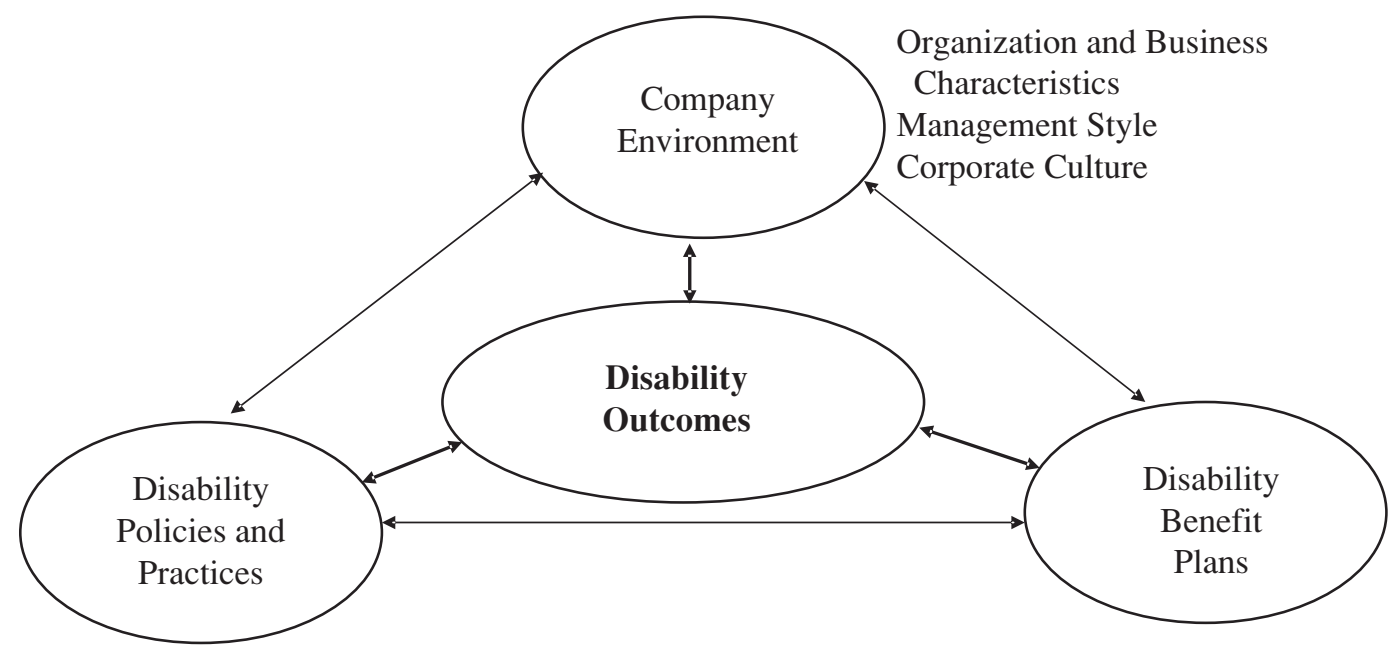


APPENDIX 2 Type of Information and Sources

\begin{tabular}{|c|c|c|}
\hline Information & Data source & Examples of interview questions \\
\hline $\begin{array}{l}\text { Company environment: } \\
\text { Organizational and } \\
\text { business } \\
\text { characteristics } \\
\text { Management style and } \\
\text { corporate culture }\end{array}$ & $\begin{array}{l}\text { Interviews with human resources } \\
\text { Interviews with occupational health } \\
\text { (e.g. case worker, nurse, medical } \\
\text { officer) } \\
\text { Document review (e.g. newspaper, } \\
\text { corporate documents) }\end{array}$ & $\begin{array}{l}\text { - How does the company demonstrate } \\
\text { concerns about retaining and developing } \\
\text { personnel? } \\
\text { - Describe the qualities that the company } \\
\text { values in its managers. } \\
\text { - Does your company conduct employee } \\
\text { surveys? How frequently? } \\
\text { - What are you trying to measure with the } \\
\text { survey? } \\
\text { - How does the company share information } \\
\text { with employees on financial status and } \\
\text { key initiatives? }\end{array}$ \\
\hline $\begin{array}{l}\text { Benefit plans } \\
\text { Short-term disability } \\
\text { Long-term disability }\end{array}$ & $\begin{array}{l}\text { Document review } \\
\text { Interview with occupational health and } \\
\text { human resources }\end{array}$ & $\begin{array}{l}\text { - When does short-term disability "kick- } \\
\text { in"? } \\
\text { - Does your plan design provide any } \\
\text { incentives for early return to work? } \\
\text { - Are there any differences between the } \\
\text { short-term disability plan in place in } \\
\text { 1996-1998 and the one in place today? If } \\
\text { yes, describe differences. Why was the } \\
\text { plan changed? }\end{array}$ \\
\hline $\begin{array}{c}\text { Disability management } \\
\text { policies and practices }\end{array}$ & $\begin{array}{l}\text { Document review of written disability } \\
\text { policies } \\
\text { Interviews with occupational health } \\
\text { and human resources } \\
\text { Review of medical chart abstract } \\
\text { Focus group interview }\end{array}$ & $\begin{array}{l}\text { - Describe your prevention programs (e.g. } \\
\text { screening, health/risk appraisals). } \\
\text { - Describe health education programs you } \\
\text { have in place. } \\
\text { - How is the availability of this program } \\
\text { communicated to staff? } \\
\text { - What system do you use to report } \\
\text { - How do you identify absent workers? } \\
\text { - When is intervention initiated? } \\
\text { - Do you have case managers? } \\
\text { - How much time does the case worker/ } \\
\text { nurse spend with each individual? }\end{array}$ \\
\hline Outcomes & Medical records & \\
\hline
\end{tabular}

